\title{
Distal 1/3 of the Common Bile Duct Adenocarcinoma
}

National Cancer Institute

\section{Source}

National Cancer Institute. Distal 1/3 of the Common Bile Duct Adenocarcinoma. NCI

Thesaurus. Code C7976.

An adenocarcinoma that arises from the distal third of the common bile duct. 